\section{Menace of Typhus}

According to an editorial in the Medical Officer of February 21, the prospect of typhus reaching Great Britain is more than likely, but the spread of the disease can be as certainly checked by extermination of lice as smallpox can be by vaccination. The distribution of typhus at the present time is mainly confined to Spain, North Africa and Eastern Europe. In October and November 1941 less than twenty cases a week were noted in the civil population of Germany. On the other hand, the article states that if the Russian counter-offensive becomes a rout and Germany is invaded, it would be impossible to prevent the disease spreading to the civil population of Germany and to all the occupied countries in Europe. Unless, however, the Germans invade Britain en masse, this country is not likely to be over-run by typhus. No case of typhus in Great Britain has been recorded for more than ten years, and there have been only rare and small outbreaks for the past half-century, in contrast with Ireland where there is an endemic focus in Connaught. The unlikelihood of the disease gaining a foothold in Great Britain is increased by the uncertainty of the head louse conveying the disease, the comparative rarity of body lice in our population and the comparative facility of body delousing.

\section{University Grants}

Sir KIngsiey Wood has announced in a written reply to a question in the House of Commons that the Government is to maintain its grant for 1942 to the universities at its existing level. He recalled that, in view of the vital part played by the universities in the life of the community, the importance of maintaining so far as possible standards of university education and the essential contribution of the universities towards the national effort, the Government decided early in 1941 to keep the universities grant at the 1939 and 1940 figure, namely, $£ 2,149,000$. The impact of the war on university finance has so far been less severe than was expected. On the other hand, while the repair of physical damage resulting from enemy action can be dealt with under the existing war damage legislation, the repair of war damage is by no means the only problem, involving large demands on university funds, which will arise on the conclusion of hostilities. In reaching a decision, the Government had in mind these points, and had also considered a report from the University Grants Committee reviewing the whole situation.

\section{University of London}

THE degree of D.Sc. has been conferred on the following : Dr. G. W. Scott Blair (National Institute for Research in Dairying) ; Dr. A. H. Cook (Imperial College of Science and Technology); Mr. C. L. Hewett (Royal Cancer Hospital (Free) and the Sir John Cass Technical Institute); Mr. Alexander King (Imperial College of Science and Technology); Mr. M. A. Phillips (Buttersea Polytechnic); Dr. Eugene Rothstein (Imperial College of Science and Technology); Dr. Frank Smithson (Birkbeck College); Prof. F. R. Winton (University professor of pharmacology in University College).

The William Julius Mickle Fellowship has been awarded to Prof. Alexander Fleming, professor of bacteriology in St. Mary's Hospital Medical School.

Regulations have been adopted for the recently instituted certificate of proficiency in radio-physics.

\section{Scholarships in Electrical Engineering}

Applications, which must be received not later than April 15, are invited for the following scholar. ships awarded by the Institution of Electrical Engineers (Savoy Place, London, W.C.2) : Duddell Scholarship (value $£ 150$ per annum, tenable for three years): Open to British subjects under nineteen years of age on July 1, 1942, who have passed the matriculation examination of a British university or an examination exempting from matriculation and who wish to take up a whole-time day course in electrical engineering; Silvanus Thompson Scholarship (value $£ 100$ per annum and tuition fees, tenable for two years, renewable in approved cases for a third year): For works employees who are the sons of parents of limited means. Open to British subjects under twenty-two years of age on July 1, 1942, who (a) have served a minimum apprenticeship (or its equivalent) of three years at an approved electrical engineering works, and $(b)$ in addition to having taken full advantage of available opportunities for technical education, have acquired a marked degree of skill, and/or shown evidence of originality. The successful candidate will be required to take up a whole-time day course in electrical engineering at an approved university or technical college; William Beedie Esson Scholarship (value $\$ 120$ per annum, tenable for two years, renewable in approved cases for a third year): For works employees who are the sons of parents of limited means. Open to British subjects under twenty-two years of age on July 1, 1942, who have served a minimum apprenticeship (or its equivalent) of three years at an approved electrical engineering works. The successful candidate will be required to take up a whole-time day course in electrical engineering at an approved university or technical college.

\section{Announcements}

THE Medical Research Council has appointed Prof. A. W. M. Ellis, formerly University professor of medicine at the London Hospital, to a whole-time position on its scientific staff as director of research in industrial medicine. The investigations to be undertaken by Prof. Ellis and his assistants will in the first instance be directed to problems of industrial toxicology which are of special importance during the War.

For the second year, the Rockefeller Foundation has made a grant to enable the Royal Society to assist scientific societies and associations to meet the financial difficulties involved in the publication at the present time of scientific journals. This generosity, which last year benefited a number of bodies, will be widely appreciated.

THE Royal Society of Arts has awarded the annual Thomas Gray Memorial Trust Prize of $£ 50$, for an invention advancing the science or practice of navigation, to Mr. T. E. Metcalfe, of Windsor, for the seaman's protective suit devised by him. This suit, which, when not in use, folds into a compact bundle, weighing about $3 \mathrm{lb}$., forms a complete covering of water- and wind-proof material to be put on when a shipwrecked person reaches a lifeboat or raft. It is being provided by the Ministry of War Transport on a wide scale, and has already saved many men from death by exposure to the elements. 